\title{
Seasonal variations of glaciochemical, isotopic and stratigraphic properties in Siple Dome (Antarctica) surface snow
}

\author{
K. J. Kreutz, ${ }^{1}$ P. A. Mayewski, ${ }^{1}$ M. S. Thickler, ${ }^{1}$ S. I. Whitlow, ${ }^{1}$ J.W. C. White, ${ }^{2}$ \\ C. A. Shuman, ${ }^{3}$ C. F. Raymond, ${ }^{4}$ H. Conway, ${ }^{4}$ J. R. MaConnell ${ }^{5}$ \\ ${ }^{1}$ Climate Change Research Center, Institute for the Study of Earth, Oceans and Space and Department of Earth Sciences, \\ University of New Hampshire, Durham, NH 03824, U.S.A. \\ ${ }^{2}$ Stable Isotope Laboratory, Institute of Arctic and Alpine Research, University of Colorado, Boulder, CO 80303, U.S.A. \\ ${ }^{3}$ NASA/Goddard Space Flight Center, Code 971, Greenbelt, MD 20771, U.S.A. \\ ${ }^{4}$ Geophysics Program, University of Washington, Seattle, WA 98195-1650, U.S.A. \\ ${ }^{5}$ Desert Research Institute, University of Nevada System, Reno, NV 89506, U.S.A.
}

\begin{abstract}
Six snow-pit records recovered from Siple Dome, West Antarctica, during 1994 are used to study seasonal variations in chemical (major ion and $\mathrm{H}_{2} \mathrm{O}_{2}$ ), isotopic (deuterium) and physical stratigraphic properties during the 1988-94 period. Comparison of $\delta \mathrm{D}$ measurements and satellite-derived brightness temperature for the Siple Dome area suggests that most seasonal $\delta \mathrm{D}$ maxima occur within \pm 4 weeks of each 1 January. Several other chemical species $\left(\mathrm{H}_{2} \mathrm{O}_{2}\right.$, non-sea-salt (nss) $\mathrm{SO}_{4}{ }^{2-}$, methanesulfonic acid and $\left.\mathrm{NO}_{3}{ }^{-}\right)$show coeval peaks with $\delta \mathrm{D}$, together providing an accurate method for identifying summer accumulation. Sea-salt-derived species generally peak during winter/spring, but episodic input is noted throughout some years. No reliable seasonal signal is identified in species with continental sources $\left(\mathrm{nssCa}^{2+}, \mathrm{nss}^{2+}\right), \mathrm{NH}_{4}{ }^{+}$or $\mathrm{nssCl}^{-}$. Visible strata such as large depthhoar layers $(>5 \mathrm{~cm})$ are associated with summer accumulation and its metamorphosis, but smaller hoar layers and crusts are more difficult to interpret. A multi-parameter approach is found to provide the most accurate dating of these snow-pit records, and is used to determine annual layer thicknesses at each site. Significant spatial accumulation variability exists on an annual basis, but mean accumulation in the sampled $10 \mathrm{~km}^{2}$ grid for the $1988-94$ period is fairly uniform.
\end{abstract}

\section{INTRODUGTION}

Interpreting past environmental change from snow, firn and ice-core records depends in large part upon accurate construction of depth/age relationships. Several different physical and chemical techniques (visible stratigraphy, stable isotopes, ion chemistry, $\mathrm{H}_{2} \mathrm{O}_{2}$, electrical conductivity, laser light scattering from dust) have been developed to identify seasonal layering in polar ice sheets (e.g. Dansgaard, 1964; Murozumi and others, 1969; Hammer and others, 1978; Herron and Langway, 1979; Hammer, 1980; Warburton and Young, 1981; Mumford and Peel, 1982; Legrand and Delmas, 1984; Whitlow and others, 1992; Minikin and others, 1994). Each of these techniques, used independently, has an associated error (identifying a year where one does not exist, or omitting a year where one does exist), which increases with depth or age (Alley and others, 1990). Therefore, combining several of these techniques in a multi-parameter dating approach provides a more accurate means for reconstructing

\footnotetext{
* Present address: Department of Marine Chemistry and Geochemistry, Woods Hole Oceanographic Institution, Woods Hole, MA 02543, U.S.A.
}

accumulation histories and interpreting chemical variability through time. The advantage of such an approach has been demonstrated in the Greenland Ice Core Project (GRIP) and Greenland Ice Sheet Project II (GISP2) ice-core records, which currently provide the longest, most continuously dated records of annual layer accumulation available (Dahl-Jensen and others, 1993; Meese and others, 1994).

A deep ice-coring project at Siple Dome, West Antarctica $\left(81.65^{\circ} \mathrm{S}, 148.81^{\circ} \mathrm{W}\right.$; Fig. 1), intends to produce a new Southern Hemisphere paleoclimatic record similar in length and resolution to the GISP2 and GRIP records. As with the Summit (Greenland) records, a full suite of chemical and physical parameters will be measured on the Siple Dome core which can be used for core-dating, assuming seasonal signals can be identified. Several of these parameters were measured in snow-pit samples collected at Siple Dome during the 199495 reconnaissance field season (Mayewski and others, 1995; Raymond and others, 1995). Here we present chemical, isotopic and stratigraphic results from the upper $2 \mathrm{~m}$ of the 1994 snow pits, and evaluate the seasonal signal represented by each parameter. Our goal is to estimate snow-pit annual layer thicknesses based on these parameters, and hence provide information on recent accumulation rates and aid future snow-pit and ice-core interpretations at Siple Dome. 


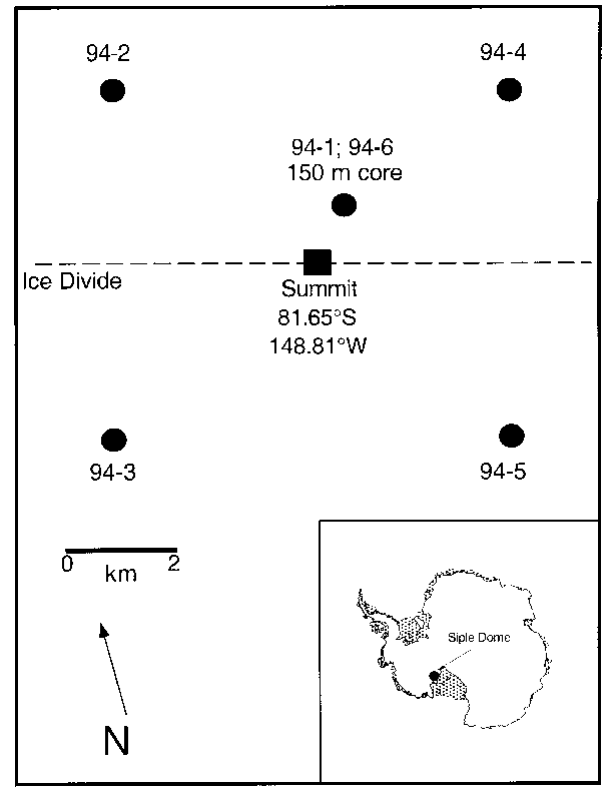

Fig. 1. Location map for 1994 Siple Dome snow pits. Pit 94-6 is located $\sim 300$ m northeast of pit $94-1$, and hence is not represented as a separate point at this scale.

\section{METHODS}

Six snow pits were sampled at Siple Dome $(621 \mathrm{ma}$ a.s.l. (Raymond and others, 1995); $25^{\circ} \mathrm{C} 10 \mathrm{~m}$ temperature (Mayewski and others, 1995)) during the 1994-95 field season (Fig. 1). Four $2 \mathrm{~m}$ pits (94-2, 94-3, 94-4 and 94-5) are located on the corners of a $10 \mathrm{~km}^{2}$ grid centered on the Siple Dome summit (Raymond and others, 1995); one $4 \mathrm{~m}$ deep pit (94-1) is located at the site of a $150 \mathrm{~m}$ ice core (Kreutz and others, 1997a); and one $1 \mathrm{~m}$ pit (94-6) is located $\sim 300 \mathrm{~m}$ northeast of the 1994 drill site (Mayewski and others, 1995). The sampling interval is $2 \mathrm{~cm}$ for all pits except pit 94-6, where it is $1 \mathrm{~cm}$. Snow-pit sampling was performed by workers wearing non-particulating suits, polyethylene gloves and particle masks. Samples were collected into precleaned polyethylene containers for frozen shipment and stored below $-15^{\circ} \mathrm{C}$ until melting, immediately prior to chemical analysis. Analysis of major cations $\left(\mathrm{Na}^{+}, \mathrm{K}^{+}\right.$, $\left.\mathrm{NH}_{4}{ }^{+}, \mathrm{Mg}^{2+}, \mathrm{Ca}^{2+}\right)$, anions $\left(\mathrm{Cl}^{-}, \mathrm{NO}_{3}{ }^{-}, \mathrm{SO}_{4}{ }^{2-}\right)$ and methanesulfonate (MSA) in all samples was performed at the University of New Hampshire using Dionex 4000 series instruments. Cations were analyzed via suppressed chromatography with a Dionex CS12 column, $0.125 \mathrm{~mL}$ loop and $20 \mathrm{mM}$ MSA eluent. Anions were analyzed with a Dionex ASll column, $0.75 \mathrm{~mL}$ loop and $6.0 \mathrm{mM} \mathrm{NaOH}$ eluent. MSA measurements were made with an ASll column, $1.5 \mathrm{~mL}$ loop and $0.5 \mathrm{mM} \mathrm{NaOH}$ eluent. Mean ion concentrations for the 1994 pits are given in Kreutz and Mayewski (1999). Partitioning of sea-salt (ss) and non-sea-salt (nss) fractions is based upon the model described in O'Brien and others (1995). Snow-pit samples were analyzed for isotopic $(\delta \mathrm{D})$ composition at the University of Colorado with uncertainties of $\pm 0.5 \%$ (Vaughn and others, 1998), and are reported in \%o per mil relative to standard mean ocean water (SMOW). $\mathrm{H}_{2} \mathrm{O}_{2}$ concentration was determined using the peroxidase-based fluorescence method (Sigg and others, 1992) at the University of Arizona. Physical properties measured in the 1994 pits include density, texture, strength and temperature (Raymond and others, 1995).
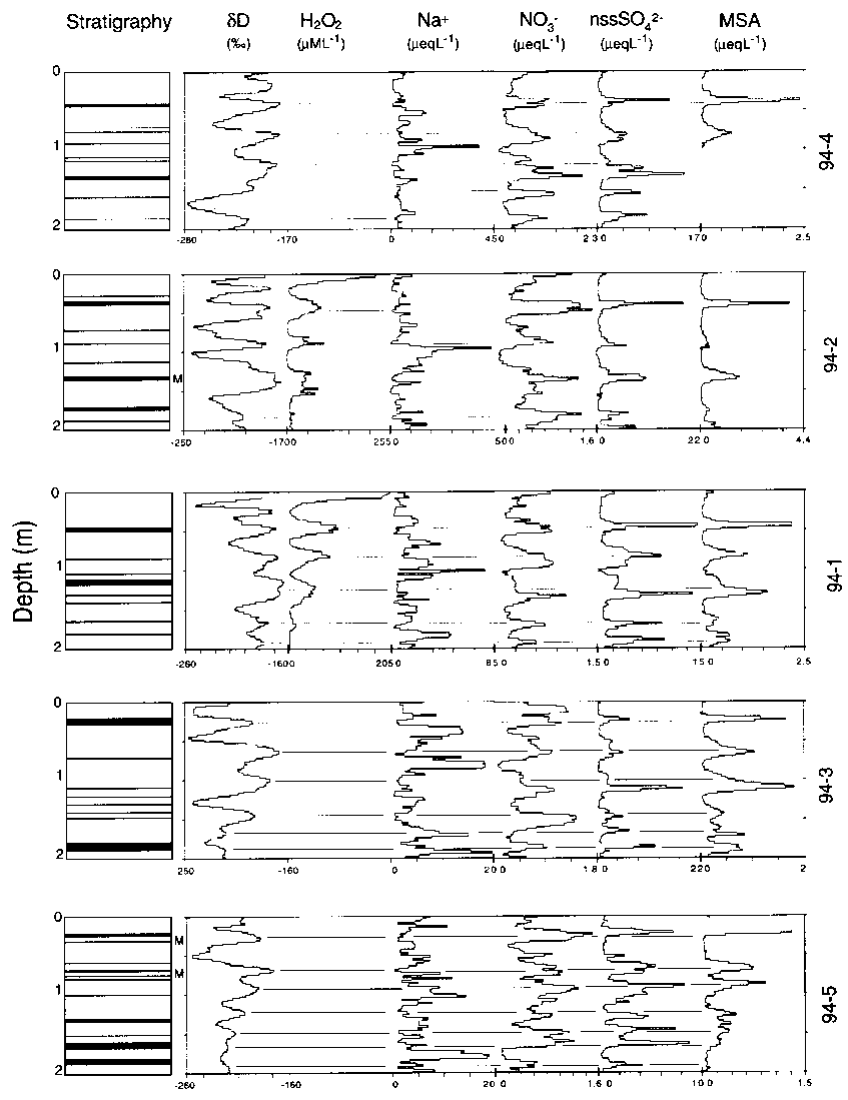

Fig. 2. Stratigraphic, isotopic and glaciochemical measurements in $2 m$ Siple Dome snow-pit samples during 1994. Snow pits are arranged according to geographic position on Siple Dome: pits $94-4$ and $94-2$ are located $5 \mathrm{~km}$ north of the east-west-trending Siple Dome ice divide (Raymond and others, 1995); pit 94-1 is $\sim 0.7 \mathrm{~km}$ north of the ice divide; and pits $94-3$ and $94-5$ are $5 \mathrm{~km}$ south of the ice divide. $\mathrm{H}_{2} \mathrm{O}_{2}$ concentration was not measured in pits 94-4, 94-3 and 94-5, and sample volume did not permit MSA measurement in pit $94-4$ and the upper $15 \mathrm{~cm}$ of pit 94-5. Hoar layers in stratigraphic profiles are represented by dark bands, and the locations of observed melt layers $(2-5 \mathrm{~mm}$ thick) are marked $(M)$ to the right of the stratigraphic profiles.

\section{PHYSICAL STRATIGRAPHY}

The use of visible strata in the analysis and dating of snow pits, firn and ice cores is a common glaciological tool, and has been documented on the Siple Coast, West Antarctica (Alley, 1988; Alley and Bentley, 1988). Low-density layers are formed at or near the surface when intense insolation warms snow $1 \mathrm{~cm}$ below the surface by as much as $5^{\circ} \mathrm{C}$ above the ambient air temperature (Alley and others, 1990). Vapor diffusion down this steep temperature gradient causes nearsurface mass loss accompanied by rapid grain growth, yielding a hoar layer. Subsequent snowfalls that bury a surface hoar layer typically are finer-grained, denser and have a smoother upper surface than the hoar. Hoar layers are rare or absent in winter snow, and therefore their presence provides a method for identifying buried summer layers (Alley, 1988; Shuman and others, 1998).

Stratigraphic layers (hoar and melt layers) identified in the Siple Dome snowpack are presented in Figure 2. The principal feature of the stratigraphy is the pervasive presence of faceted crystals in the snow and firn. In each pit, there are approximately 8-10 prominent soft layers of very strongly faceted, coarse, poorly bonded grains spread over the $2 \mathrm{~m}$ 
sampling. Certain of these low-density layers possess a distinctive appearance, with large, symmetrical grains extending from underlying and overlying strata. One possible explanation for this phenomenon is vapor-gradient reversal during formation, causing transport both to the surface and down to the snowpack. As noted by Alley (1988) at a nearby location (ridge $\mathrm{BC}$ ), such low-density layers are generally indicative of summer processes, and therefore allow a first approximation of time-depth relationships in the 1994 snow pits. Variability in hoar-layer thickness and number in each pit, however, makes unambiguous identification of annual layers difficult. Unfortunately, surface observations of the timing, extent, preservation and frequency of hoar formation at Siple Dome are not yet available, and therefore a detailed understanding of hoar formation and preservation is currently lacking. Although the counting of hoar complexes has been shown to be accurate to $1 \%$ at century-length timescales in Greenland (Alley and others, 1990), we may assume that some years in West Antarctica lack an identifiable hoar event or that other years have two or more events.

In addition to low-density layers, a small number $(3-5$ per $2 \mathrm{~m}$ pit) of thin (1-2 mm), hard crusts were identified in all pits. The majority of these crusts are not associated with significant depth-hoar layers, suggesting that their formation is not related to summer temperatures. Release of latent heat from katabatic winds descending from the West Antarctic polar plateau may provide sufficiently warm temperatures to produce these crusts. Occasional melt layers $(2-5 \mathrm{~mm})$ were also noted, but stratigraphy and temperature profiles indicate that melting is not an important metamorphic and transfer process in comparison to vapor diffusion caused by strong temperature gradients. As discussed below, these apparent melt layers produce no noticeable redistribution of water-soluble constituents in the snowpack.

\section{STABLE ISOTOPES}

Like visual stratigraphy, the use of seasonal variations in snow, firn and ice stable-isotope ratios to identify annual layering is an established technique (Hammer and others, 1978). Although several factors affect isotopic ratios, numerous studies in polar regions have demonstrated the relationship between increased summer surface temperatures and more positive isotopic ratios (e.g. Dansgaard, 1964; Jouzel and others, 1997). $\delta$ D profiles in 1994 Siple Dome snow pits (Fig. 2) display significant ( 100\%o) amplitude oscillations, which are assumed to represent winter/summer temperature variability. To investigate $\delta \mathrm{D}$ timing, high-resolution $(1 \mathrm{~cm}$ sampling) measurements from pit 94-6 were compared to satellite-derived passive microwave brightness temperatures (Fig. 3). This technique is based on the theory that the relationship between brightness temperature and physical temperature is a function of the physical temperature of the near-snow surface multiplied by its emissivity (Shuman and others, 1995).

The brightness-temperature record at Siple Dome contains distinct maxima during the 1992-93, 1993-94 and 1994-95 austral summers, and also shows peaks of lesser amplitude during corresponding winter periods (Fig. 3; Table 1). Such winter peaks may be related to intrusion of warm, moisture-laden marine air during periods of intense cyclonic activity, causing increased surface temperatures and reduced emissivity (due to fresh snow deposition). The

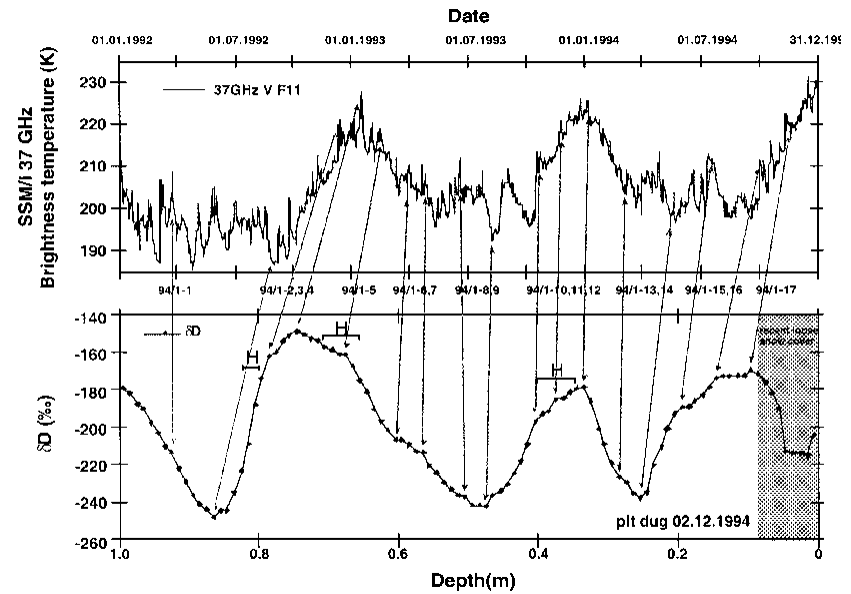

\begin{abstract}
Fig. 3. Comparison of deuterium ( $\delta D)$ ratios in pit $94-6$ and brightness temperature derived from Special Sensor Microwave/Imager (SSM/I) data in pit 94-6. The satellite data used are from daily-averaged, $37 \mathrm{GHz}$, vertical polarization; brightness temperatures are from SSM/I ( sensor F11) for the $25 \mathrm{~km}^{2}$ grid covering pit 94-6. Hoar layers ( H) identified in pit $94-6$ are noted.
\end{abstract}

uppermost isotope peak $(\sim 0.080-0.25 \mathrm{~m})$ corresponds to the onset of summer 1994-95 conditions, based on the sampling date for this snow pit, 94-6 (2 December 1994). Decreased $\delta \mathrm{D}$ in the upper $10 \mathrm{~cm}$ is likely related to fresh surface snow present during sampling (pit 94-6 was the last one sampled during the 1994-95 field season, so the $\sim 10 \mathrm{~cm}$ of fresh snow at the surface is not present in other pit profiles). We match the next obvious $\delta \mathrm{D}$ peak and hoar event $(\sim 0.25-0.45 \mathrm{~m})$ with summer 1993-94. A broad peak in isotope values occurs between 0.6 and $0.85 \mathrm{~m}$, corresponding to summer 1992-93 deposition. Two hoar events are identified in this depth interval, and it therefore appears that grouping these two hoar events together as a summer complex is necessary for correct identification of a specific single summer season. Regardless, these results from pit 94-6 suggest that hoar for-

Table 1. Summary of information derived from $\delta D /$ brightnesstemperature comparison

\begin{tabular}{|c|c|c|c|}
\hline \multirow[t]{2}{*}{ Match point } & \multirow[t]{2}{*}{ Date } & \multirow{2}{*}{$\begin{array}{c}S S M / I 37 G_{z} \\
\text { brightness temp. } \\
\mathrm{K}\end{array}$} & \multirow{2}{*}{$\begin{array}{l}\delta D \\
\% 0\end{array}$} \\
\hline & & & \\
\hline $94 / 1-17$ & 11 November 1994 & 222.6 & -169.4 \\
\hline $94 / 1-16$ & 3 October 1994 & 212 & -173.6 \\
\hline $94 / 1-15$ & 14 July 1994 & 213 & -189.2 \\
\hline $94 / 1-14$ & 14 May 1994 & 196.1 & -237.2 \\
\hline $94 / 1-13$ & 6 March 1994 & 203.3 & -226.4 \\
\hline $94 / 1-12$ & 1 January 1994 & 225.7 & -177.9 \\
\hline $94 / 1-11$ & 25 November 1993 & 220.8 & -185.1 \\
\hline $94 / 1-10$ & 18 October 1993 & 213.2 & -196.8 \\
\hline $94 / 1-9$ & 9 August 1993 & 192.2 & -241.6 \\
\hline $94 / 1-8$ & 17 June 1993 & 212.1 & -237 \\
\hline $94 / 1-7$ & 21 April 1993 & 210.7 & -213.2 \\
\hline $94 / 1-6$ & 28 March 1993 & 202.2 & -205.9 \\
\hline $94 / 1-5$ & 15 February 1993 & 219.5 & -160.6 \\
\hline $94 / 1-4$ & 17 January 1993 & 227.7 & -148.1 \\
\hline $94 / 1-3$ & 14 December 1992 & 221.5 & -161.9 \\
\hline $94 / 1-2$ & 31 August 1992 & 186.6 & -247.8 \\
\hline $94 / 1-1$ & 24 March 1992 & 208.8 & -213.1 \\
\hline
\end{tabular}


mation and the $\delta \mathrm{D}$ signal are recording summer intervals. Determining the exact timing of the $\delta \mathrm{D}$ peak preserved in the snowpack is difficult without snow-depth data; however, based on the above results and those of other studies in coastal Antarctic regions (Van Ommen and Morgan, 1997), $\delta$ D peaks likely occur within \pm 4 weeks of 1 January.

Using the relationships observed between hoar formation and isotopic composition in pit 94-6, we examine the remaining 1994 snow pits for hoar-formation timing (Fig. 2). In all pits, substantial $(>5 \mathrm{~cm})$ hoar layers correspond to summer $\delta \mathrm{D}$ maxima. Hoar events thinner than $5 \mathrm{~cm}$ are not always associated with summer layers based on comparison with $\delta \mathrm{D}$ profiles. No relation is noted between $\delta \mathrm{D}$ peak amplitude and hoar thickness. Indeed, predicting a $\delta \mathrm{D}$ profile based on hoar layers alone proves to be difficult, at least in this set of snow pits. Melt layers and thin crusts do not appear to have any definite relationship with $\delta \mathrm{D}$, as these stratigraphic features occur during both $\delta \mathrm{D}$ maxima and minima.

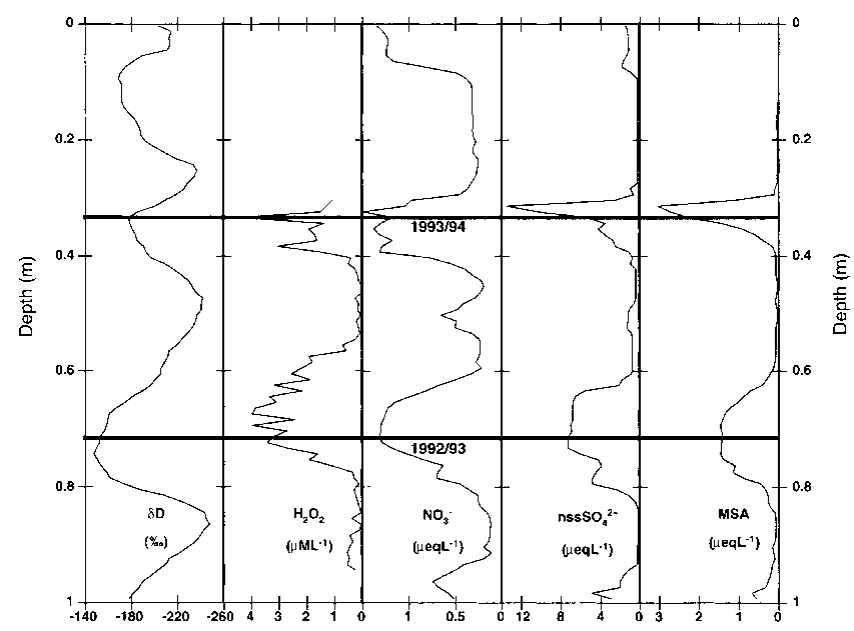

Fig. 4. Comparison of deuterium ( $\delta D)$, physical stratigraphy, $\mathrm{H}_{2} \mathrm{O}_{2}$ and major-ion concentrations $\left(\mathrm{NO}_{3}^{-}, \mathrm{nsSO}_{4}{ }^{2-}\right.$ and MSA) in pit $94-6$.

\section{HYDROGEN PEROXIDE}

$\mathrm{H}_{2} \mathrm{O}_{2}$ is produced in the atmosphere by photochemical reactions involving hydroxyl radicals, so its atmospheric concentration reflects local atmospheric chemistry and ultraviolet intensity (Beer and others, 1991). $\mathrm{H}_{2} \mathrm{O}_{2}$ is a so-called "reversibly deposited species" in snow (Bales and Choi, 1996), and therefore exhibits strong gas-phase exchange and post-depositional signal modification. Surface concentrations in central Greenland and South Pole snow pits exceed those in previously buried summer layers, with losses being greater at the lower-accumulation-rate site (South Pole; Sigg and Neftel, 1988; Whitlow and others, 1992; McConnell and others, 1998). Nevertheless, peak $\mathrm{H}_{2} \mathrm{O}_{2}$ concentrations in surface snow can provide an important indication of summer layers in the snowpack.

$\mathrm{H}_{2} \mathrm{O}_{2}$ concentrations in 1994 Siple Dome snow pits are presented in Figures 2 and 4. Comparison of $\mathrm{H}_{2} \mathrm{O}_{2}$ and $\delta \mathrm{D}$ profiles suggests that $\mathrm{H}_{2} \mathrm{O}_{2}$ peaks during or slightly after $\delta \mathrm{D}$ maxima. This finding is consistent with physically based modeling results using measured parameters (temperature, accumulation rate) at Siple Dome, which also suggest a latesummer peak for $\mathrm{H}_{2} \mathrm{O}_{2}$ (McConnell, 1997). Further exam- ination identifies a $\delta \mathrm{D}$ peak in the upper $40 \mathrm{~cm}$ of pits $94-1$ and 94-2 which does not have an associated $\mathrm{H}_{2} \mathrm{O}_{2}$ maximum. As noted below, this apparently anomalous $\delta \mathrm{D}$ maximum also occurs in pit 94-4, based on comparison with major-ion profiles. A possible explanation for this event may be related to two positive excursions in the brightnesstemperature record seen during winter (April-October) 1994 (Fig. 3). Such events may indicate intrusion of warm, marine air during intense cyclonic activity, accounting for deposition of isotopically heavy snow. This anomalous $\delta \mathrm{D}$ event appears to be confined to pits on the north side of the Siple Dome ice divide.

\section{MAJOR IONS}

On seasonal time-scales, a correlation likely exists between aerosol and snow ion concentrations, enabling ion concentration profiles in snow to be used as a dating tool (e.g. Herron and Langway, 1979; Warburton and Young, 1981; Mumford and Peel, 1982; Legrand and Delmas, 1984; Mayewski and Legrand, 1990; Mosley-Thompson and others, 1991; Whitlow and others, 1992; Minikin and others, 1994). Sulfur species $\left(\mathrm{SO}_{4}{ }^{2-}\right.$ and MSA) dominate the ion content of summer Antarctic aerosol and snowpack, and are primarily of marine origin (oxidation of dimethylsulfide; Wagenbach, 1996). Although the sources of nitrogen species $\left(\mathrm{NO}_{3}{ }^{-}\right.$and $\left.\mathrm{NH}_{4}{ }^{+}\right)$ in the Antarctic atmosphere are not well understood, $\mathrm{NO}_{3}{ }^{-}$ has been shown to peak during the late-spring/summer season in aerosol measurements (Wagenbach and others, 1988; Savoie and others, 1992) and in snow (Mayewski and Legrand, 1990; Whitlow and others, 1992; Dibb and Whitlow, 1996). Sea-salt-derived species $\left(\mathrm{Na}^{+}, \mathrm{Cl}^{-}\right.$and $\left.\mathrm{Mg}^{2+}\right)$, which dominate the total ion burden of Siple Dome surface snow, generally peak during the winter and spring (July-November) months in coastal and polar-plateau aerosols and snow (Tuncel and others, 1989; Savoie and others, 1992; Wagenbach, 1996). Because this peak occurs when sea-ice extent is at a maximum, increased meridional transport during winter is most likely responsible for the sea-salt maxima (Kreutz and others, 1997a).

Comparison of Siple Dome surface snow major-ion concentrations with isotopic, $\mathrm{H}_{2} \mathrm{O}_{2}$ and stratigraphic measurements reveals seasonal signals in several species (Figs 2 and 4). Non-sea-salt $\mathrm{SO}_{4}{ }^{2-}$ and MSA profiles display maxima generally coincident with $\delta \mathrm{D}$ and $\mathrm{H}_{2} \mathrm{O}_{2}$ peaks. Timing of both $\mathrm{nssSO}_{4}{ }^{2-}$ and MSA peaks appears consistent with observations of a peak in Southern Ocean productivity in early/mid-summer (Gibson and others, 1989). A recent comparison of continuous aerosol measurements and firn-core nssSO ${ }_{4}{ }^{2-}$ concentrations at South Pole (Bergin and others, 1998) demonstrates a consistent summer peak in sulfate aerosol and firn concentration. Therefore, based on observed $\mathrm{nssSO}_{4}{ }^{2-}$ profiles at Siple Dome and elsewhere, it appears that $\mathrm{nssSO}_{4}{ }^{2-}$ concentrations provide a consistent and accurate method for annual-layer dating, particularly at coastal sites such as Siple Dome. $\mathrm{NO}_{3}{ }^{-}$concentrations at Siple Dome peak are generally in phase with nss $\mathrm{SO}_{4}{ }^{2-}, \delta \mathrm{D}$ and $\mathrm{H}_{2} \mathrm{O}_{2}$. The timing of the summer $\mathrm{NO}_{3}{ }^{-}$peak may be related to increased stratosphere/troposphere exchange as the polar stratospheric vortex breaks down with the onset of sunlit conditions (Mayewski and Legrand, 1990; Mulvaney and Wolff, 1993).

Sea-salt concentrations (represented in Figure 2 by $\mathrm{Na}^{+}$) 


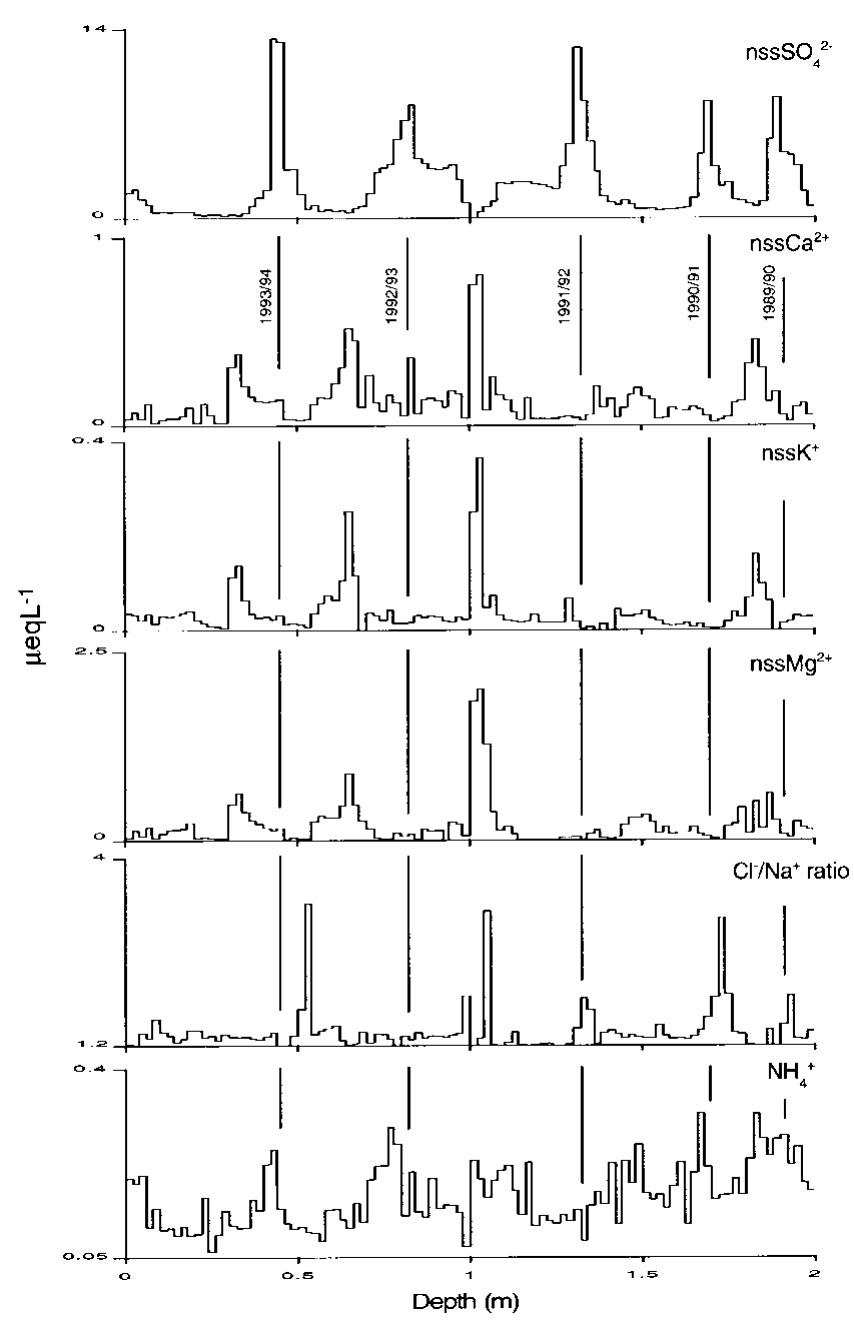

Fig. 5. Comparison of $n s s \mathrm{SO}_{4}{ }^{2-}$, $n s s \mathrm{Ca}^{2+}$, nss $\mathrm{K}^{+}$and nss $\mathrm{Mg}^{2+}$ concentrations, $\mathrm{Cl}^{-} / \mathrm{Na}$ ratios and $\mathrm{NH}_{4}^{+}$concentrations in pit 94-1. Pit 94-1 is presented here because it is located at the site of a 150 mice core (Kreutz and others, 1997a). The temporal pattern of variability demonstrated for these species in pit 94-1 is consistent in all other pits.

generally peak during winter (indicated by $\mathrm{nsSO}_{4}{ }^{2-}, \delta \mathrm{D}$ and $\mathrm{H}_{2} \mathrm{O}_{2}$ minima). Whereas South Pole snow-pit profiles usually show one $\mathrm{Na}^{+}$peak per year (Whitlow and others, 1992), Siple Dome $\mathrm{Na}^{+}$profiles contain more than one. This is likely due to the relatively coastal location of Siple Dome and its lower elevation $(621 \mathrm{~m})$. Thus, sea-salt input is episodic, and depends on synoptic-scale marine cyclogenesis, which occurs throughout the year in the high southern latitudes (Hogan, 1997). The majority of sea-salt input, however, likely occurs during winter (August-November), based on atmospheric-aerosol composition data from South Pole (Bodhaine and others, 1986). Frequent intrusions of marine air were also identified as the cause of significant sea-salt peaks in Ross Ice Shelf snow pits (Warburton and Young, 1981). Using sea-salt species as a primary dating tool at Siple Dome is not viable; however, sea-salt profiles can be used to verify winter troughs in other species.

Peaks in the $\mathrm{Cl}^{-} / \mathrm{Na}^{+}$ratio (Fig. 5), which are thought to reflect input of $\mathrm{HCl}$ in the summer from the interaction of $\mathrm{H}_{2} \mathrm{SO}_{4}$ and long-traveled sea-salt aerosols (Legrand and Delmas, 1988; Whitlow and others, 1992), peak prior to $\mathrm{nssSO}_{4}{ }^{2-}$. The high sea-salt concentrations at Siple Dome cause the $\mathrm{Cl}^{-}$/ $\mathrm{Na}^{+}$ratio, unlike that at South Pole, to be close to sea-water

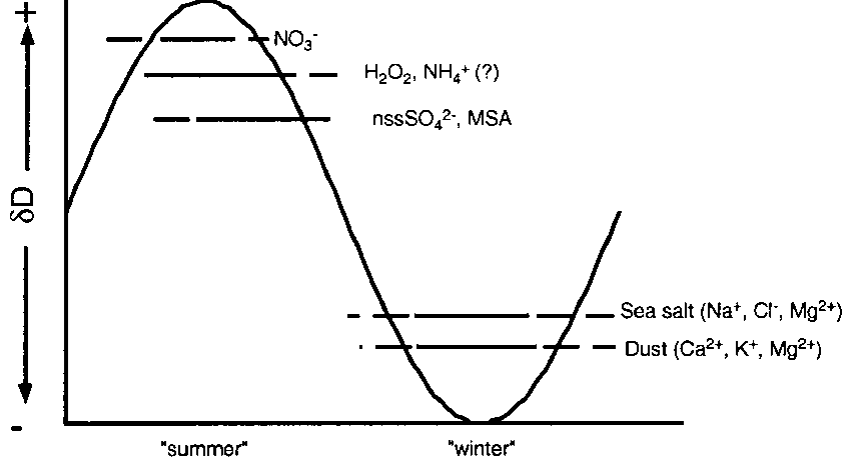

Fig. 6. Summary of seasonal input timing at Siple Dome, relative to an idealized $\delta D$ curve (after Whitlow and others, 1992). Solid lines indicate when maximum concentrations frequently occur, and dashed extensions represent the range where peaks are sometimes noted.

values (1.5) for the majority of samples, and therefore $\mathrm{Cl}^{-} / \mathrm{Na}^{+}$ ratios do not appear to be an accurate dating tool.

Although $\mathrm{NH}_{4}{ }^{+}$shows a weak summer maximum in three out of five snow-pit years (Fig. 5), low $\mathrm{NH}_{4}{ }^{+}$concentrations and potential for contamination preclude using $\mathrm{NH}_{4}{ }^{+}$as a reliable seasonal indicator at Siple Dome. Non-sea-salt fractions of $\mathrm{Ca}^{2+}, \mathrm{K}^{+}$and $\mathrm{Mg}^{2+}$, which are likely related to longtraveled, continentally derived crustal salts (Whitlow and others, 1992), consistently peak during winter (Fig. 5). Peak concentrations, however, may be due to high sea-salt concentrations and subsequent partitioning artifacts. Therefore, $\mathrm{nssCa}^{2+}, \mathrm{nssK}^{+}$and $\mathrm{nssMg}^{2+}$ concentration profiles are not likely to be an accurate means of identifying annual layers.

Figure 6 provides a schematic summary of chemical input timing relative to an idealized isotopic profile at Siple Dome. In general, results from these Siple Dome snow pits are consistent with seasonal variations in snow and aerosol chemistry reported from other Antarctic locations (South Pole (Whitlow and others, 1992), G.V. Neumayer (Wagenbach and others, 1988), Mawson (Savoie and others, 1992), Berkner Island (Wagenbach and others, 1994), Ross Ice Shelf (Warburton and Young, 1981), Dyer Plateau (Cole-Dai and others, 1995), Filchner-Ronne Ice Shelf (Minikin and others, 1994)), and with seasonal ion variations noted in the 1994 Siple Dome $150 \mathrm{~m}$ core (Kreutz and others, 1998). Of the limited set of parameters investigated here, the most reliable summer indicators in the 1994 Siple Dome snow pits appear to be nssSO ${ }_{4}{ }^{2-}, \delta \mathrm{D}, \mathrm{H}_{2} \mathrm{O}_{2}, \mathrm{MSA}$ and $\mathrm{NO}_{3}{ }^{-}$. Where large hoar layers can be identified, they are also useful, but thin layers do not provide unique annual associations. Seasalt species peaks can be used to estimate winter deposition, but caution must be used since sea-salt peaks are shown to occur throughout the year on an event basis. Thus, a multiparameter approach is beneficial for accurately dating Siple Dome snow-pit, firn and ice-core records.

\section{RESULTS OF ANNUAL-LAYER GOUNTING IN 1994 SNOW PITS}

Applying the above dating scheme to the 1994 Siple Dome snow pits results in the mean annual accumulation rates presented in Figure 7. Although it appears that a slight gradient in accumulation rate exists (increasing to the north), the short (5-7 year) snow-pit records and large interannual accu- 


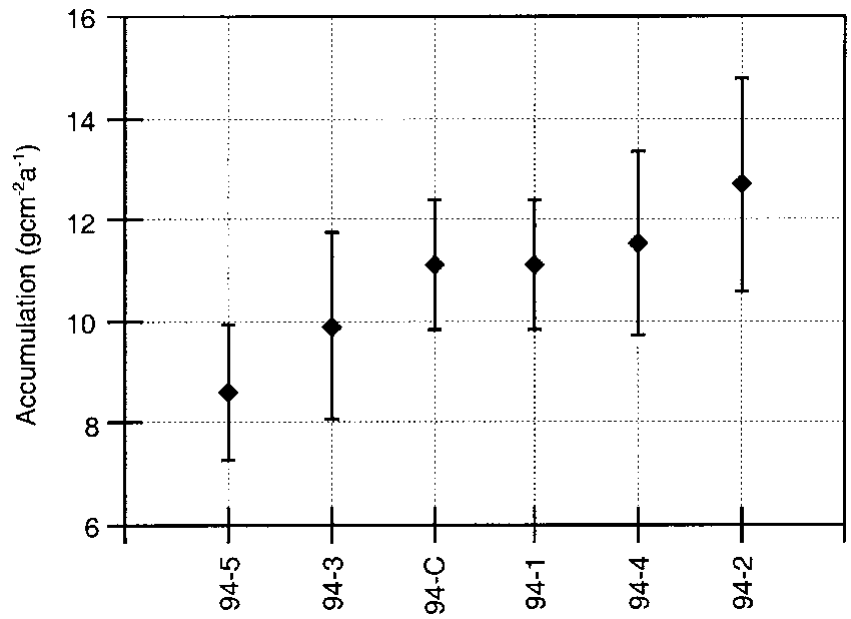

Fig. 7. Mean annual accumulation-rate estimates from snow pits and 150 mice core (denoted as $94-C$; Kreutz and others, 1997a) collected at Siple Dome during 1994. Pits 94-1, $94-2$ and 94 -4 and the 1994 core which are north of the ice divide are to the right, while pits to the south of the divide (94-3 and 94-5) are to the left. Average values represent slightly different time periods, based on the number of years of accumulation present in the upper $2 m$ at each site (5years (1990-94) for pits $94-2$ and 94-4; 6 years (1989-94) for pit 94-3; 7 years (1988-94) for pits 94-1 and 94-5; and 7 years (1988-94) for the core record). Error bars represent \pm 1 standard error unit.

mulation variability preclude a statistical difference for all but two pits (94-2 and 94-5). Major-ion profiles from an expanded array of snow pits ( $\pm 30 \mathrm{~km}$ of the divide) on Siple Dome (collected during the 1996-97 season), however, indicate that this gradient is significant in terms of accumulation and ion flux (Kreutz and others, 1997b). Such a gradient in accumulation rate is consistent with modeled moisture flux into the Ross Sea/West Antarctic region Cullather and others, 1996) and hence across the roughly east-west-trending Siple Dome ice divide.

Comparison of accumulation rates in the 1994 snow pits with results from the $150 \mathrm{~m}$ core drilled at Siple Dome is also presented in Figure 7 for the 7 year period (1988-94) of overlap. Values for the 1988-94 period in both pit 94-1 and the 1994 core are roughly equal, as would be expected due to the small spatial offset between the two records $(\sim 1 \mathrm{~m})$. Accumulation estimates for 1988-94 from the two drill-site records $\left(11.1 \mathrm{~g} \mathrm{~cm}^{-2} \mathrm{a}^{-1}\right)$ are also similar to the 1150 year mean accumulation $\left(11.9 \mathrm{~g} \mathrm{~cm}^{-2} \mathrm{a}^{-1}\right.$, density $0.9 \mathrm{~g} \mathrm{~cm}^{-3}$; Kreutz and others, 1997a). Despite the significant interannual and decadal-scale variability present in the core accumulation record, there is no appreciable change prior to the onset of or during the Little Ice Age (Kreutz and others, 1997a). Therefore, the recent accumulation regime at Siple Dome, at least near the flow divide, may be representative of conditions present during the last millennium.

\section{CONGLUSIONS}

Results presented here, while only in the top $2 \mathrm{~m}$ of the Siple Dome snowpack, suggest that seasonal signals in several parameters do exist and will enable construction of an accurate depth/age scale in deeper cores recovered from Siple Dome. Discrete and continuous ion measurements in the 1994 Siple
Dome 150 m core (Kreutz and others, 1997a) provide evidence of this, at least for $15 \%$ of the Siple Dome ice thickness (Raymond and others, 1995). Modeling results from Siple Dome suggest that annual layers will reach sub-centimeter thickness at about 600-700 $\mathrm{m}$ depth, which is below the predicted depth of the Wisconsin/Holocene transition ( 550$650 \mathrm{~m}$; Nereson and others, 1996). In their study, Nereson and others (1996) suggest that if annual stratigraphic or chemical signals exist and have been preserved in the ice, they may be resolved throughout the Holocene. Post-depositional processes are known to affect ionic (Steffensen and others, 1997; Kreutz and others, 1998), $\mathrm{H}_{2} \mathrm{O}_{2}$ (McConnell, 1997) and isotopic (Hammer and others, 1978) records at depth in various icecore records, and therefore interpretation of the various seasonal chemical variations (Kreutz and others, in press) may become more difficult. Despite this, a multi-parameter approach using both chemical and visible-stratigraphic techniques may still be expected to provide accurate dating of a long time-series ice-core record from Siple Dome.

\section{AGKNOWLEDGEMENTS}

We thank colleagues in the field (Q. Yang, A. Gades, R. Jacobel and T. Scambos), the Siple Dome Science Coordination Office (Desert Research Institute, University of Nevada), the Polar Ice Coring Office (University of Nebraska, Lincoln), Antarctic Support Associates, Navy Squadron VXE-6 and the 109th Air National Guard. S. Johnsen and K. Goto-Azuma made helpful comments on the manuscript. Financial support for this project was provided by the U.S. National Science Foundation Office of Polar Programs (OPP 9316564 (UNH), OPP 9420648 (UW)).

\section{REFERENGES}

Alley, R. B. 1988. Concerning the deposition and diagenesis of strata in polar firn. f. Glaciol., 34(118), 283-290.

Alley, R. B. and C. R. Bentley. 1988. Ice-core analysis on the Siple Coast of West Antarctica. Ann. Glaciol., 11, 1-7.

Alley, R. B., E. S. Saltzman, K. M. Cuffey and J. J. Fitzpatrick. 1990. Summertime formation of depth hoar in central Greenland. Geophys. Res. Lett., 17(12), 2393-2396.

Bales, R. C. and J. Choi. 1996. Conceptual framework for interpretation of exchange processes. In Wolff, E. W. and R. C. Bales, eds. Chemical exchange between the atmosphere and polar snow. Berlin, etc., Springer-Verlag, 319-338. (NATO ASI Series I: Global Environmental Change 43.)

Beer, J. and 15 others. 1991. Seasonal variations in the concentrations of ${ }^{10} \mathrm{Be}$, $\mathrm{Cl}^{-}, \mathrm{NO}_{3}{ }^{-}, \mathrm{SO}_{4}{ }^{2-}, \mathrm{H}_{2} \mathrm{O}_{2},{ }^{210} \mathrm{~Pb},{ }^{3} \mathrm{H}$, mineral dust and ${ }^{18} \mathrm{O}$ in Greenland snow. Atmos. Environ., Ser. A, 25(5-6), 899-904.

Bergin, M., E. A. Meyerson, J. E. Dibb and P. A. Mayewski. 1998. Relationship between continuous aerosol measurements and firn core chemistry over a 10 year period at the South Pole. Geophys. Res. Lett., 25 (8), 1189-1192.

Bodhaine, B. A., J. J. Deluisi, J. M. Harris, P. Houmere and S. Bauman. 1986. Aerosol measurements at the South Pole. Tellus, 38B(3-4), 223-235.

Cole-Dai, J., L. G. Thompson and E. Mosley-Thompson. 1995. A 485 year record of atmospheric chloride, nitrate and sulfate: results of chemical analysis of ice cores from Dyer Plateau, Antarctic Peninsula. Ann. Glaciol., 21, 182-188.

Cullather, R. I., D. H. Bromwich and M. L. van Woert. 1996. Interannual variations in Antarctic precipitation related to El-Niño-Southern Oscillation. 7. Geophys. Res., 101 (D14), 19,109-19,118.

Dahl-Jensen, D., S. J. Johnsen, C. U. Hammer, H. B. Clausen and J. Jouzel. 1993. Past accumulation rates derived from observed annual layers in the GRIP ice core from Summit, central Greenland. In Peltier, W. R., ed. Ice in the climate system. Berlin, etc., Springer-Verlag, 517-532. (NATO ASI Series I: Global Environmental Change 12.

Dansgaard, W. 1964. Stable isotopes in precipitation. Tellus, 16(4), 436-468.

Dibb, J. E. and S. Whitlow. 1996. Recent climatic anomalies and their impact on snow chemistry at South Pole, 1987-1994. Geophys. Res. Lett., 23(10), $1115-1118$. 
Gibson, J. A. E., R. C. Garrick, H. R. Burton and A. R. McTaggart. 1989. Dimethylsulphide and the alga Phaeocystis pouchetii in Antarctic coastal waters. Mar. Biol., 104(2), 339-346.

Hammer, C. U. 1980. Acidity of polar ice cores in relation to absolute dating, past volcanism, and radio-echoes. F. Glaciol., 25(93), 359-372.

Hammer, C. U., H. B. Clausen, W. Dansgaard, N. Gundestrup, S. J. Johnsen and N. Reeh. 1978. Dating of Greenland ice cores by flow models, isotopes, volcanic debris, and continental dust. f. Glaciol., 20(82), 3-26.

Herron, M. M. and C. C. Langway, Jr. 1979. Dating of Ross Ice Shelf cores by chemical analysis. F. Glaciol., 24(90), 345-357.

Hogan, A. 1997. A synthesis of warm air advection to the South Polar Plateau. 7. Geophys. Res., 102(D12), 14,009-14,020.

Jouzel, J. and 12 others. 1997. On the validity of the temperature reconstruction from water isotopes in ice cores. F. Geophys. Res., 102(C12), 26,471-26,487.

Kreutz, K. J. and P. A. Mayewski. 1999. Spatial variability of Antarctic surface snow glaciochemistry: implications for paleoatmospheric circulation reconstructions. Antarct. Sci., 11 (1), 105-118.

Kreutz, K. J., P. A. Mayewski, L. D. Meeker, M. S. Twickler, S. I. Whitlow and I. I. Pittalwala. 1997a. Bipolar changes in atmospheric circulation during the Little Ice Age. Science, 277 (5330), 1294-1296.

Kreutz, K. J., P. A. Mayewski, M. S. Twickler, S. I. Whitlow and L. D. Meeker. 1997b. Glaciochemical studies at Siple Dome, West Antarctica during the 1996-97 season. Antarct. F. U.S., 32(5), Review 1997, 46-48.

Kreutz, K. J., P. A. Mayewski, S. I. Whitlow and M. S. Twickler. 1998. Limited migration of soluble ionic species in a Siple Dome, Antarctica, ice core. Ann. Glaciol., 27, 371-377.

Kreutz, K. J., P. A. Mayewski, L. D. Meeker, M. S. Twickler and S. I. Whitlow. In press. Continuous glaciochemical measurements on the Siple Dome deep ice core. Antarct. F. U.S.

Legrand, M. R. and R.J. Delmas. 1984. The ionic balance of Antarctic snow: a 10 year detailed record. Atmos. Environ., 18(9), 1867-1874.

Legrand, M. R. and R. J. Delmas. 1988. Soluble impurities in four Antarctic ice cores over the last 30000 years. Ann. Glaciol., 10, 116-120.

Mayewski, P. A. and M. Legrand. 1990. Recent increase in nitrate concentration of Antarctic snow. Nature, 346(6281), 258-260.

Mayewski, P. A., M. S. Twickler and S. I. Whitlow. 1995. The Siple Dome ice core - reconnaissance glaciochemistry. Antarct. 7. U.S., 30(5), Review 1995, 85-87.

McConnell, J. R. 1997. Investigation of the atmosphere-snow transfer process for hydrogen peroxide. (Ph.D. thesis, University of Arizona.)

McConnell, J. R., R. C. Bales, R.W. Stewart, A. M. Thompson, M. R. Albert and R. Ramos. 1998. Physically based modeling of atmosphereto-snow-to-firn transfer of $\mathrm{H}_{2} \mathrm{O}_{2}$ at South Pole. F. Geophys. Res., 103(D9), $10,561-10,570$

Meese, D. A. and 8 others. 1994. The accumulation record from the GISP2 core as an indicator of climate change throughout the Holocene. Science, 266(5191), 1680-1682.

Minikin, A., D. Wagenbach, W. Graf and J. Kipfstuhl. 1994. Spatial and seasonal variations of the snow chemistry at the central Filchner-Ronne Ice Shelf, Antarctica. Ann. Glaciol., 20, 283-290.

Mosley-Thompson, E., J. Dai, L. G. Thompson, P. M. Grootes, J. K. Arbogast andJ. F. Paskievitch. 1991. Glaciological studies at Siple Station (Antarctica): potential ice-core paleoclimatic record. F. Glaciol., 37(125), 11-22.

Mulvaney, R. and E.W. Wolff. 1993. Evidence for winter/spring denitrification of the stratosphere in the nitrate record of Antarctic firn cores. $\mathcal{F}$. Geophys. Res., 98 (D3), 5213-5220.

Mumford, J.W. and D. A. Peel. 1982. Microparticles, marine salts and stable isotopes in a shallow firn core from the Antarctic Peninsula. Br. Antarct. Surv. Bull. 56, 37-47.

Murozumi, M., T. J. Chow and C. C. Patterson. 1969. Chemical concentration of pollutant lead aerosols, terrestrial dusts and sea salts in Greenland and Antarctic snow strata. Geochim. Cosmochim. Acta, 33(10), 1247-1294.

Nereson, N. A., E. D. Waddington, C. F. Raymond and H. P. Jacobson. 1996. Predicted age-depth scales for Siple Dome and inland WAIS ice cores in West Antarctica. Geophys. Res. Lett., 23 (22), 3163-3166.

O’Brien, S. R., P. A. Mayewski, L. D. Meeker, D. A. Meese, M. S. Twickler and S. I. Whitlow. 1995. Complexity of Holocene climate as reconstructed from a Greenland ice core. Science, 270(5244), 1962-1964.

Raymond, C. R., N. A. Nereson, A. M. Gades, H. Conway, R. Jacobel and T. Scambos. 1995. Geometry and stratigraphy of Siple Dome, Antarctica. Antarct. F. U.S., 30 (5), Review 1995, 91-93.

Savoie, D. L., J. M. Prospero, R. J. Larsen and E. S. Saltzman. 1992. Nitrogen and sulfur species in aerosols at Mawson, Antarctica, and their relationship to natural radionuclides. F. Atmos. Chem., 14(1-4), 181-204.

Shuman, C. A., R. B. Alley, S. Anandakrishnan, J.W. C. White, P. M. Grootes and C. R. Stearns. 1995. Temperature and accumulation at the Greenland Summit: comparison of high-resolution isotope profiles and satellite passive microwave brightness temperature trends. F. Geophys. Res., 100 (D5), 9165-9177.

Shuman, C. A. and 6 others. 1998. Temperature history and accumulation timing for the snowpack at GISP2, central Greenland. F. Glaciol., 44(146), 21-30.

Sigg, A. and A. Neftel. 1988. Seasonal variations in hydrogen peroxide in polar ice cores. Ann. Glaciol., 10, 157-162.

Sigg, A., T. Staffelbach and A. Neftel. 1992. Gas phase measurements of hydrogen peroxide in Greenland and their meaning for the interpretation of $\mathrm{H}_{2} \mathrm{O}_{2}$ records in ice cores. 7. Atmos. Chem., 14(1-4), 223-232.

Steffensen, J. P., H. B. Clausen, C. U. Hammer, M. Legrand and M. de Angelis. 1997. The chemical composition of cold events within the Eemian section of the Greenland Ice Core Project ice core from Summit, Greenland. F. Geophys. Res., $102(\mathrm{Cl} 2), 26,747-26,754$.

Tuncel, G., N. K. Aras and W. H. Zoller. 1989. Temporal variations and sources of elements in the South Pole atmosphere. 1. Nonenriched and moderately enriched elements. f. Geophys. Res., 94(D10), 13,025-13,038.

Van Ommen, T. D. and V. Morgan. 1997. Calibrating the ice core paleothermometer using seasonality. F. Geophys. Res., 102(D8), 9351-9357.

Vaughn, B. H., and J.W. C. White, M. Delmotte, M. Trolier, O. Cattani and M. Stievenard. 1998. An automated system for hydrogen isotope analysis of water. Chem. Glaciol., 152, 309-319.

Wagenbach, D. 1996. Coastal Antarctica: atmospheric chemical composition and atmospheric transport. In Wolff, E. W. and R. C. Bales, eds. Chemical exchange between the atmosphere and polar snow. Berlin, etc., Springer-Verlag, 173-199. (NATO ASI Series I: Global Environmental Change 43.)

Wagenbach, D., U. Görlach, K. Moser and K. O. Münnich. 1988. Coastal Antarctic aerosol: the seasonal pattern of its chemical composition. Tellus, 40B (5), 426-436.

Wagenbach, D. and 6 others. 1994. Reconnaissance of chemical and isotopic firn properties on top of Berkner Island, Antarctica. Ann. Glaciol., 20, 307-312.

Warburton, J. A. and L. G. Young. 1981. Estimating ratios of snow accumulation in Antarctica by chemical methods. F. Glaciol., 27(96), 347-357.

Whitlow, S., P. A. Mayewski and J. E. Dibb. 1992. A comparison of major chemical species seasonal concentration and accumulation at the South Pole and Summit, Greenland. Atmos. Environ., 26A(11), 2045-2054. 